\title{
NONTHERMAL EFFECTS OF MOBILE PHONE RADIATIONS ON HUMAN HEART RATE, BLOOD PRESSURE, AND SUGAR LEVEL
}

\author{
BASANDRAI D ${ }^{1,2 *}$, DHAMI A $\mathrm{K}^{2}$, BEDI R $\mathrm{K}^{3}$ \\ ${ }^{1}$ Department of Physics, I.K. Gujral Punjab Technical University, Jalandhar, Punjab, India. ${ }^{2}$ Department of Physics, Lovely Professional \\ University, Phagwara, Punjab, India. ${ }^{3}$ Department of Applied Sciences, Satyam Institute of Engineering \& Technology, Amritsar: \\ Email: basandraideepak@yahoo.com.
}

Received: 11 February 2017, Revised and Accepted: 13 April 2017

ABSTRACT

Objective: A single-blinded pilot study has been conducted to investigate the effect of cell phone radiation on the human heart.

Methods: Experimental work has been conducted in Jalandhar-based hospital under the supervision of a cardiologist. During experimental work, electrocardiogram (ECG), blood pressure (BP) level, and sugar level have been examined before and after cell phone radiation exposure. For ECG analysis, the parameters such as heart rate, rhythm, mechanism, axis, P wave, PR interval, QRS complex, ST segment, T wave, and QT interval have been examined in the study.

Results: No significant variations in the results of above-mentioned parameter has been observed before and after acute exposure of cell phones radiations by placing cell phone closer to heart.

Conclusion: The result of this study concludes that mobile phone radiations do not interfere with any electrical activity of the human heart, BP, and sugar level in healthy individuals.

Keywords: Cell phone radio waves, Blood pressure, Electrocardiogram, Blood sugar level.

(C) 2017 The Authors. Published by Innovare Academic Sciences Pvt Ltd. This is an open access article under the CC BY license (http://creativecommons. org/licenses/by/4. 0/) DOI: http://dx.doi.org/10.22159/ajpcr.2017.v10i7.17655

\section{INTRODUCTION}

The popularity of mobile phone tremendously increased in the last decennium. With the advent in $3 \mathrm{G}$ and $4 \mathrm{G}$ technology, now mobile phone serves wider multimedia applications in addition to its basic phone functioning. Mobile phone communicates through lower frequencies of electromagnetic radiation called non-ionizing radiation. Hence, people concern regarding the biological effect of non-ionizing radiation has been a topic of debate from last decade. Non-ionizing radiation with frequency more than $100 \mathrm{KHz}$ and higher produces thermal effects [1]. Such effects are known for increasing the exposed tissue temperature more than the whole body temperature, which can affect the normal working of concerned tissue and hence give rise to various deleterious health hazards. Increase in cancer cases, cataracts formation in eye tissue, DNA damage, and neurological problem are credit to thermal effect of non-ionizing radiation [2-7]. In addition to thermal effects, nonionizing radiations also produce nonthermal effects which are equally hazardous. Such effects can increase the temperature of exposed tissue less than the normal temperature fluctuation. These types of effects are known to initiate cancer and increase resistance to anticancer drugs [8]. Other than cancer these nonthermal, electromagnetic radiation leads to several different types of condition such as genetic damage, birth defects, increased blood pressure (BP), and headache and sleep disorder.

In general, men tend to keep their cell phone either in ringing mode or vibrating mode inside breast pocket close to heart, resulting in exposure to cell phone radiation. Human heart is a specialized muscle which pumps blood inside human body regularly. Working of heart is divided into two parts which work simultaneously. In one part, blood coming back from tissue and organs enter into the right side of the heart, which then pumps to lungs. In the second part, blood returning from lungs enters the left side of the heart, which then pumps to rest part of the human body including heart muscle itself. For the smooth functioning of body hearts play a key role. However, very few studies are available which had studied the hazardous effects of cell phone radiation on human heart. In one of such studies, heart rate variability has been assessed for the study of cardiac autonomic function $[9,10]$. In another study, a very small change in heart beat has been observed after exposing to cell phone radiation [11]. However, reports are available otherwise too, in which no significant variation has been found in pulse rate and BP before and after use of cell phone [12]. Therefore, more research work is required to access unambiguously, the heart susceptibility toward cell phone radiations. Moreover, the most of the analysis was made by placing cell phone closer to ear not to heart which can further affect the working of heart. So for the better understanding of radiation's impact on heart, it's become mandatory to place cell phone closer to heart. The present work has been done using electrocardiogram (ECG), arm pulse rate monitor, and blood glucose monitor by placing cell phone closer to heart for the analysis of the cell phone radiations impact on human heart, BP level, and sugar level.

\section{METHODS}

The participant was a 32-year-old male with body mass index (BMI) 37.4. BMI has been calculated as (weight) $(\mathrm{Kg}) /(\text { height })^{2}\left(\mathrm{~m}^{2}\right)$. Participant was using a mobile phone from the past 12 years and a smartphone with $3 G$ technology from the past 1 year, with average duration of $1 \mathrm{hr}$ usage per day. Person was nondiabetic, no heart diseases, and no BP problem. ECG has been performed on the person in the cardiology unit of Jalandhar-based hospital under the supervision of cardiologist. The electrocardiograph contain in-built computer analysis program that delivers information about the heart rate and rhythm, frontal plane axis of the QRS, P and T-waves, PR durations of waves and intervals including the corrected QT interval (QTc). This instrument is also capable of recording cardiac arrhythmias. Person is nonalcoholic and does not intake any caffeine drink from the past 1 year. The analysis 
was performed in an air-conditioned room with temperature of about $24^{\circ} \mathrm{C}$ to avoid any diurnal variations in BP, ECG, and sugar level.

The BP was measured in sitting posture from the left arm using arm pulse rate monitor. In addition to this, sugar level was also measured under similar condition using blood glucose monitor. Dual SIM mobile phone Galaxy grand 19082 with Wi-Fi 802.11, dual-band, hotspot, and SAR $0.24 \mathrm{~W} / \mathrm{Kg}$ (head) and $0.29 \mathrm{~W} / \mathrm{Kg}$ (body) have been used as a radiofrequency source. During exposure, mobile phone was placed closer to left chest in calling mode. To ensure participant stable mood, a light music was playing during the experiment. BP, sugar level, and ECG have been recorded before and after, during the exposure duration.

\section{RESULT}

Results obtained from ECG and measurement made for BP and sugar level has been plotted in Fig. 1 and Tables 1-3.

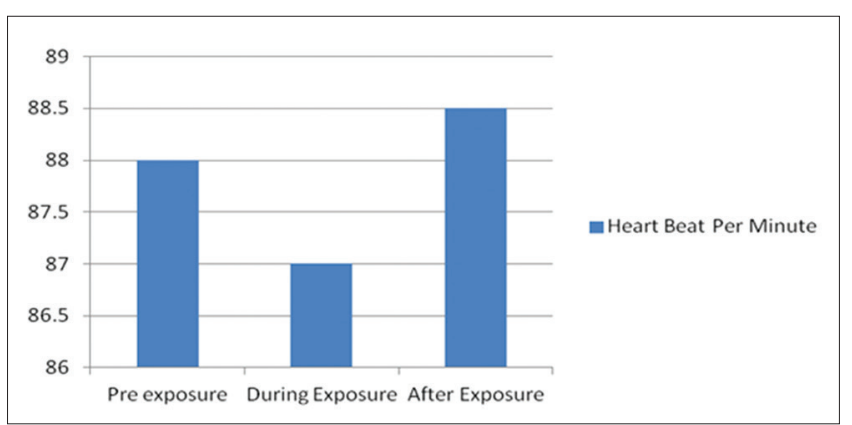

Fig. 1: Heartbeat per minute pre, during and after mobile phone exposure

Table 1: Electrocardiogram analysis pre, during and after mobile phone exposure

\begin{tabular}{|c|c|c|c|}
\hline Condition & Pre exposure & $\begin{array}{l}\text { During } \\
\text { exposure }\end{array}$ & $\begin{array}{l}\text { After } \\
\text { exposure }\end{array}$ \\
\hline Heart rate & 92 & 91 & 92 \\
\hline Rhythm & Normal sinus & Normal sinus & Normal sinus \\
\hline Mechanism & Very regular & Very regular & Very regular \\
\hline Axis & 0 degree & 0 degree & 0 degree \\
\hline $\mathrm{P}$ wave & Normal & Normal & Normal \\
\hline PR interval & 0.16 seconds & 0.16 seconds & 0.16 seconds \\
\hline QRS complex & Normal & Normal & Normal \\
\hline ST segment & Normal & Normal & Normal \\
\hline $\mathrm{T}$ wave & Normal & Normal & Normal \\
\hline QT interval & 0.32 seconds & 0.32 seconds & 0.32 seconds \\
\hline
\end{tabular}

Table 2: Blood pressure (mmHg) pre, during and after mobile phone exposure

\begin{tabular}{llll}
\hline Condition & Pre exposure & $\begin{array}{l}\text { During } \\
\text { exposure }\end{array}$ & $\begin{array}{l}\text { After } \\
\text { exposure }\end{array}$ \\
\hline $\begin{array}{l}\text { Systolic blood } \\
\text { pressure (mmHg) }\end{array}$ & 112 & 112 & 114 \\
$\begin{array}{l}\text { Diastolic blood } \\
\text { pressure (mmHg) }\end{array}$ & 82 & 80 & 82 \\
\hline
\end{tabular}

Table 3: Blood sugar level (mg/dL) pre, during and after mobile phone exposure

\begin{tabular}{llll}
\hline Condition & Pre exposure & $\begin{array}{l}\text { During } \\
\text { exposure }\end{array}$ & $\begin{array}{l}\text { After } \\
\text { exposure }\end{array}$ \\
\hline $\begin{array}{l}\text { Blood sugar } \\
\text { level }(\mathrm{mg} / \mathrm{dL})\end{array}$ & 90 & 90 & 91 \\
\hline
\end{tabular}

\section{DISCUSSION}

In this study, all the ECG tracing parameters lie in normal range before and after an acute exposure to mobile phone radiations. According to American Heart Association, the normal human heart rate should be lie in between 60 and $100 \mathrm{bpm}$ and in this study average heart rate was found to be $88 \mathrm{bpm}$ [13]. Hence, we can say that cell phone radiation has no effect on the number of contraction of heart per minute. The first upward movement of ECG tracing which indicates regular pumping of blood into the ventricles called $\mathrm{P}$ wave is found to be normal before and after exposure. The QRS complex which begins with a downward deflection which ensures ventricular depolarization and contraction also found to be normal during analysis. Similarly, no change has been found in transit time (PR interval) during which electrical signal travel from sinus mode to ventricles. For a healthy heart, safe PR interval should be between 0.12 seconds and 0.20 seconds and QT interval should be $<0.40$ seconds. In the current analysis, both PR and QT interval lie in safe zone. Average PR and QT interval was found to be 0.16 seconds and 0.32 seconds, respectively. $\mathrm{T}$ wave representing ventricular repolarization and other parameters such as rhythm, mechanism, and ST segment was found to be regular during and after an acute exposure. Results of the present ECG study are in close agreement with the work done by of Barker et al., $[9,10]$. This might be due to the fact that autonomic nervous system ANS which modulates the function of circulatory system and provide regular cardiovascular rhythm has no perfect reception system for EM waves for frequencies of either $900 \mathrm{MHz}$ or $1,800 \mathrm{MHz}$. The small fraction of available power that affects the ANS can be considered as noise and luckily human ANS is tolerant against noise. So no significant variation has been noticed. Hence, we can say that a mobile phone wave does not interfere with the electrical rhythm of heart waves, which ensure the smooth function of the heart during and after exposure.

In addition to ECG, no change has been observed in the case of BP level. $\mathrm{BP}$ rises with every heartbeat and falls when heart relaxes. The normal range for systolic and diastolic BP lies in between 120 and $80 \mathrm{mmHg}$. In this study, average range was found to be $113-81 \mathrm{mmHg}$, which indicates normal heart pumping. These findings show close resemblance with work done by Braune et al. [11].

Similarly, no change has been observed in blood sugar level under radiation exposure. However, these findings do not agree with the similar work done by Havas [14]. The variation in results may be attributed due to various aspects. First due to methodology, mobile phone position is closer to heart rather to ear. Second, exposure duration is small. Third, the participant is nondiabetic.

\section{CONCLUSION}

This study is single-blinded study for the analysis of cell phone radiation effect on human heart. In which no significant variation has been reported in the case of BP, sugar level, pulse rate and the electrical rhythm of the heart before and after exposure. But in future, more research work can be carried out with a people of different age groups using different methodology. For present work, exposure duration is only 6 minutes. However, men usually keep cell phone in their breast pocket for a longer duration. So for future studies can be carried out for long exposure duration.

\section{REFERENCES}

1. Adair ER, Black DR. Thermoregulatory responses to RF energy absorption. Bioelectromagnetics 2003;Suppl 6:S17-38.

2. Dolk H, Shaddick G, Walls P, Grundy C, Thakrar B, Kleinschmidt I, et al. Cancer incidence near radio and television transmitters in Great Britain. I. Sutton Coldfield transmitter. Am J Epidemiol 1997; 145(1):1-9

3. Stagg RB, Thomas WJ, Jones RA, Adey WR. DNA synthesis and cell proliferation in C6 glioma and primary glial cells exposed to a 836.55 $\mathrm{MHz}$ modulated radiofrequency field. Bioelectromagnetics $1997 ; 18(3): 230-6$ 
4. Marinelli F, La Sala D, Cicciotti G, Cattini L, Trimarchi C, Putti S, et al. Exposure to $900 \mathrm{MHz}$ electromagnetic field induces an unbalance between pro-apoptotic and pro-survival signals in T-lymphoblastoid leukemia CCRF-CEM cells. J Cell Physiol 2004;198(2):324-32.

5. Hardell L, Carlberg M. Mobile phones, cordless phones and the risk for brain tumours. Int J Oncol 2009;35(1):5-17.

6. Hirata A. Temperature increase in human eyes due to near-field and farfield exposures at $900 \mathrm{MHz}, 1.5 \mathrm{GHz}$, and 1.9GHz. IEEE 2005;4:68-76.

7. Basandrai D, Dhami AK. Study of thermal interaction of cell-phone radiations within human head tissues. Asian J Pharm Clin Res 2016;9(6). Available from: http://www.dx.doi.org/10.22159/ajpcr.2016. v9i6.14133.

8. French PW, Penny R, Laurence JA, McKenzie DR. Mobile phones, heat shock proteins and cancer. Differentiation 2001;67(4-5):93-7.

9. Barker AT, Jackson PR, Parry H, Coulton LA, Cook GG, Wood SM. The effect of GSM and TETRA mobile handset signals on blood pressure, catechol levels and heart rate variability. Bioelectromagnetics 2007;28(6):433-8
10. Barutcu I, Esen AM, Kaya D, Turkmen M, Karakaya O, Saglam M, et al. Do mobile phones pose a potential risk to autonomic modulation of the heart? Pacing Clin Electrophysiol 2011;34(11):1511-4.

11. Braune S, Wrocklage C, Raczek J, Gailus T, Lücking CH. Resting blood pressure increase during exposure to a radio-frequency electromagnetic field. Lancet 1998;351(9119): 1857-8

12. Umar ZU, Abubakar MB, Ige J, Igbokwe UV, Mojiminiyi FB, Isezuo SA. Effect of mobile phone radiofrequency electromagnetic fields on cardiovascular parameters in apparently healthy individuals Niger. J Physiol Sci 2014;29:137-40.

13. Target Heart Rates-AHA. Target Heart Rates. American Heart Association. 4 April; 2014. Available from: http://www.heart.org/ HEARTORG/HealthyLiving/PhysicalActivity/Target-Heart-Rates UCM_434341_Article.jsp\#.WUuZb5KGNdg. [Last retrieved on $201 \overline{4}$ May 21]

14. Havas M. Dirty electricity elevates blood sugar among electrically sensitive diabetics and may explain brittle diabetes. Electromagn Biol Med 2008; 27(2):135-46. 